\title{
THE COAGULATION-FIBRINOLYSIS SYSTEM IN MAN DURING ETHRANE@ ANAESTHESIA AND SURGERY
}

\author{
T. Oyama, M. Takiguchi, M. Nagayama; and M. Maki
}

\section{INTRODUCTION}

The CIRCULATORY AND RESPIRATORY RESPONSES to $\overline{\text { Ethrane }}{ }^{\circledR}$ have been studied since 1966 , but the effect of $\bar{E}$ thrane ${ }^{\circledR}$ on the coagulation-fibrinolysis system has not been published. The present study was undertaken to determine whether an haemorrhagic tendency may occur during surgical operations under $\overline{\mathbf{E}}$ thrane ${ }^{\circledR}$ anaesthesia in man.

\section{Subjects}

\section{Methons}

Twenty patients, undergoing gynaecological operations (mainly panhysterectomy), were the subjects of the present study. The pre-operative bleeding time, coagulation time, hepatic function and renal function were normal. None of these patients had any severe anaemia and none received a haemostatic agent. The diagnosis, type of surgery, duration of operation and anaesthesia, volume of haemorrhage, and volume of intravenous fluids administered are shown in Table I.

\section{Anaesthetic Method}

Premedication, given in the usual manner, consisted of pentobarbitone $100 \mathrm{mg}$, meperedine $35 \mathrm{mg}$, and atropine $0.5 \mathrm{mg}$.

After control blood sampling, the subject started to inhale 2 litres of oxygen and 4 litres of nitrous oxide combined with $\bar{E}$ thrane ${ }^{\$}$. Concentration of $\bar{E}$ thrane ${ }^{\circledR}$ was increased from 0.5 per cent to 2.5 per cent by opening a Fluotec ${ }^{\circledR}$ vapourizer one notch of calibration after every two or three respirations. After loss of consciousness tracheal intubation was performed with relaxation provided by injection of succinylcholine chloride $40 \mathrm{mg}$. Anaesthesia was maintained with 2 litres of oxygen and 2 litres of nitrous oxide. The Fluotec ${ }^{\circledR}$ vapourizer was kept at between 1.0 per cent and 2.0 per cent for the maintenance of anaesthesia. Curare was administered when needed. Five hundred $\mathrm{ml}$ of low molecular weight dextran was used throughout the procedure. Anaesthesia was maintained for 30 minutes before beginning the operation and during that period a maximum of $100 \mathrm{ml}$ of low molecular dextran was used. When bleeding exceeded $400 \mathrm{ml}$, whole blood was transfused.

\section{Time and Method of Blood Sampling}

Blood was withdrawn five times; immediately before induction of anaesthesia at 8.30 a.m. (which served as a control), 30 minutes after the start of anaesthesia,

From the Department of Anaesthesia, Hirosaki University School of Medicine, Hirosaki, Aomori-Ken, Japan.

-Present address: Anaesthesiology Service/112A, Veterans Administration Center, Wood (Milwaukee), Wisconsin 53193. 
TABLE I

Surgical Operations Performed

\begin{tabular}{|c|c|c|c|c|c|c|c|}
\hline Case & Age & Surgical Procedure & $\begin{array}{l}\text { Operating } \\
\text { Time }\end{array}$ & $\begin{array}{c}\text { Anaesthesia } \\
\text { Time }\end{array}$ & $\begin{array}{l}\text { Blood } \\
\text { Loss }\end{array}$ & $\begin{array}{c}\text { Blood } \\
\text { Transfusion }\end{array}$ & Fluid \\
\hline 1 & 41 & Panhysterectomy & $2^{\circ} 50^{\prime}$ & $4^{\circ} 15^{\prime}$ & 345 & 0 & 1000 \\
\hline 2 & 41 & Panhysterectomy & $4^{\circ} 00^{\prime}$ & $6^{\circ} 15^{\prime}$ & 437 & 400 & 1000 \\
\hline$\overline{3}$ & 44 & Panhysterectomy & $3^{\circ} 35^{\prime}$ & $4^{\circ} 15^{\prime}$ & 530 & 600 & 1000 \\
\hline 4 & 47 & Panhysterectomy & $5^{\circ} 37^{\prime}$ & $7^{\circ} 25^{\prime}$ & 970 & 800 & 1500 \\
\hline $\mathbf{5}$ & 46 & Panhysterectomy & $4^{\circ} 22^{\prime}$ & $5^{\circ} 07^{\prime}$ & 914 & 1000 & 1000 \\
\hline 6 & 48 & Panhysterectomy & $3^{\circ} 00^{\prime}$ & $4^{\circ} 05^{\prime}$ & 240 & 0 & 1000 \\
\hline 7 & 39 & Panhysterectomy & $2^{\circ} 55^{\prime}$ & $4^{\circ} 05^{\prime}$ & 400 & 200 & 1500 \\
\hline 8 & 46 & Panhysterectomy & $4^{\circ} 30^{\prime}$ & $5^{\circ} 15^{\prime}$ & 440 & 400 & 1500 \\
\hline 9 & 50 & Panhysterectomy & $3^{\circ} 10^{\prime}$ & $3^{\circ} \mathbf{4} 5^{\prime}$ & 430 & 200 & 1000 \\
\hline 10 & 38 & Exploratory laparotomy & $2^{\circ} 20^{\prime}$ & $3^{\circ} 05^{\prime}$ & 180 & 0 & 500 \\
\hline 11 & 60 & Panhysterectomy & $3^{\circ} 00^{\prime}$ & $3^{\circ} 40^{\prime}$ & 320 & 0 & 1500 \\
\hline 12 & 40 & Panhysterectomy & $3^{\circ} 18^{\prime}$ & $4^{\circ} 20^{\prime}$ & 262 & 0 & 1000 \\
\hline 13 & 44 & Panhysterectomy & $3^{\circ} 15^{\prime}$ & $4^{\circ} 29^{\prime}$ & 160 & 0 & 1000 \\
\hline 14 & 40 & Hysterectomy & $2^{\circ} 15^{\prime}$ & $3^{\circ} 01^{\prime}$ & 261 & 0 & 1000 \\
\hline 15 & 41 & Panhysterectomy & $3^{\circ} 10^{\prime}$ & $4^{\circ} 00^{\prime}$ & 940 & 800 & 1000 \\
\hline 16 & 47 & Panhysterectomy & $3^{\circ} 40^{\prime}$ & $4^{\circ} 25^{\prime}$ & 350 & 0 & 1000 \\
\hline 17 & 38 & Panhysterectomy & $3^{\circ} 20^{\prime}$ & $4^{\circ} 25^{\prime}$ & 700 & 680 & 1000 \\
\hline 18 & 66 & Panhysterectomy & $2^{\circ} 15^{\prime}$ & $3^{\circ} 00^{\prime}$ & 538 & 400 & 1000 \\
\hline 19 & 35 & Hysterectomy & $2^{\circ} 08^{\prime}$ & $3^{\circ} 00^{\prime}$ & 244 & 0 & 1000 \\
\hline 20 & 51 & Colpoperineorrhaphy & $1^{\circ} 35^{\prime}$ & $2^{\circ} 52^{\prime}$ & 136 & 0 & 1000 \\
\hline \multicolumn{2}{|c|}{ Mean } & & $3^{\circ} 12^{\prime}$ & $4^{\circ} 14^{\prime}$ & 439 & 274 & 1075 \\
\hline
\end{tabular}

30 minutes and 1 hour after beginning the operation, and in the recovery room when the patient was fully awake. The blood samples were taken through an indwelling polyvinyl catheter into a disposable plastic syringe which contained a mixture of nine volumes of venous blood and one volume of 3.8 per cent sodium citrate. The plasma was subjected to the determinations tabulated below and paired Student $t$-tests were employed for statistical analysis.

\section{Methods of Determinations}

(a) Platelet count (Brecher-Cronkete method)

(b) Thrombin time (seconds) (Hougie method)

(c) Partial thromboplastin time (seconds)

(d) Prothrombin time (seconds) (Quick one-stage method)

(e) Plasminogen ( $\times 10^{-3}$ P.U.) (modified Maki method)

(f) Fibrinogen (mg/100 ml) (Maki modification of the Rathoff-Menzie method)

(g) Euglobulin clot lysis time (minutes).

\section{RESULTS}

\section{Platelet Count}

The platelet count immediately before the induction of anaesthesia averaged $23.5 \pm 1.14 \times 10^{4} / \mathrm{mm}^{3}$ ( \pm S.E. ). It was $21.0 \pm 1.07 \times 10^{4} / \mathrm{mm}^{3} 30$ minutes after the start of anaesthesia, $23.1 \pm 1.4,19.9 \pm 1.63$ one hour after starting the operation and $20.6 \pm 1.0 \times 10^{1} / \mathrm{mm}^{3}$ in the recovery room. Thus, all were within the normal range and no appreciable variation was noted (Table II). 
OYAMA, et al.; COAGULATION-FIBRINOLYSIS SYSTEM

TABLE II

Platelet Count During Ẽthrane ${ }^{(}$Anaesthesia and Surgical Operation

\begin{tabular}{|c|c|c|c|c|c|c|}
\hline \multirow[b]{2}{*}{ Case } & & \multicolumn{5}{|c|}{ Platelet Count $\left(\times 10^{4} / \mathrm{mm}^{3}\right)$} \\
\hline & & Preincubation & $\begin{array}{c}\text { Anaesthesia } \\
\left(30^{\prime}\right)\end{array}$ & $\begin{array}{c}\text { Operation } \\
\left(30^{\prime}\right)\end{array}$ & $\begin{array}{c}\text { Operation } \\
\left(1^{\circ}\right)\end{array}$ & $\begin{array}{c}\text { Recovery } \\
\text { Room }\end{array}$ \\
\hline 3 & & 16.8 & 17.2 & 16.2 & 15.0 & 21.0 \\
\hline 4 & & 20.0 & 22.0 & 20.6 & 23.2 & 25.0 \\
\hline 5 & & 22.2 & 15.0 & 17.6 & 15.0 & 16.0 \\
\hline 6 & & 24.6 & 25.0 & 21.8 & 17.0 & 11.0 \\
\hline 7 & & 33.4 & 20.0 & 34.0 & 30.0 & 23.0 \\
\hline 8 & & 15.6 & 19.4 & - & 18.2 & 17.4 \\
\hline 9 & & 22.0 & 23.4 & - & 12.8 & 21.4 \\
\hline 10 & & 28.8 & 28.6 & 29.8 & 18.6 & 24.2 \\
\hline 11 & & 20.0 & 19.6 & 26.0 & 20.8 & 19.0 \\
\hline 12 & & 23.6 & 24.0 & 22.0 & 28.0 & 19.0 \\
\hline 13 & & 29.7 & 19.6 & - & - & 16.2 \\
\hline 14 & & 22.6 & 12.4 & 14.0 & 18.0 & 16.0 \\
\hline 15 & & 18.2 & 26.6 & 24.0 & 17.4 & 20.0 \\
\hline 17 & & 24.2 & 18.0 & 24.0 & 27.4 & 24.0 \\
\hline 18 & & 26.4 & 19.6 & 27.2 & 18.6 & 17.2 \\
\hline 20 & & 28.4 & 26.2 & 22.6 & 28.8 & 28.2 \\
\hline & Mean & 23.5 & 21.0 & 23.1 & 19.9 & 20.6 \\
\hline & S.E. & 1.19 & 1.07 & 1.46 & 1.63 & 1.00 \\
\hline & p & & N.S. & N.S. & N.S. & N.S. \\
\hline
\end{tabular}

$'=$ minutes. ${ }^{\circ}=$ hours. N.S. $=$ not significant.

\section{Coagulation System}

(a) Thrombin time. Prior to the induction of anaesthesia, the thrombin time averaged $12.2 \pm 0.40$ seconds ( \pm S.E. ). It was $12.6 \pm 0.56$ seconds 30 minutes after the beginning of anaesthesia and thus within the normal range. During the operation ( 30 minutes after incision) it showed some prolongation ( $14.5 \pm 1.25$ seconds), which was not a significant difference. In the recovery room, the thrombin time was $12.7 \pm 0.56$ seconds, which is a normal level (Table III).

(b) Prothrombin time. Prothrombin time was $13.7 \pm 0.38$ seconds ( \pm S.E.) before the induction of anaesthesia. It was slightly, but significantly, decreased to $13.3 \pm 0.41$ seconds 30 minutes after the start of anaesthesia and to $13.2 \pm 0.36$ seconds 30 minutes after the beginning of operation. Prothrombin times did not change and were within normal range during the operations ( $13.2 \pm 13.6$ seconds) and in the recovery room ( 13.6 seconds) (Table IV).

(c) Partial thromboplastin time (P.T.T.). Partial thromboplastin time prior to the induction of anaesthesia was $60.0 \pm 3.8$ seconds ( \pm S.E.). It decreased insignificantly to $56.7 \pm 3.06$ seconds 30 minutes after the start of anaesthesia but before the operation. P.T.T. further decreased significantly (49.6 \pm 1.94 seconds, $\mathrm{p}<0.001) 30$ minutes after the start of operation and returned to the preinduction level ( $60.3 \pm 9.3$ seconds) one hour after the start of operation. In the recovery room, however, it was again reduced significantly to $47.1 \pm 2.0$ seconds $(\mathrm{p}<0.01)$ (Table V).

\section{Results on the Fibrinolysis System}

(a) Plasma plasminogen level before the induction of anaesthesia was $16.3 \pm$ 
TABLE III

Thrombin Time During Ėthrane® Anaesthesia and Surgical Operation

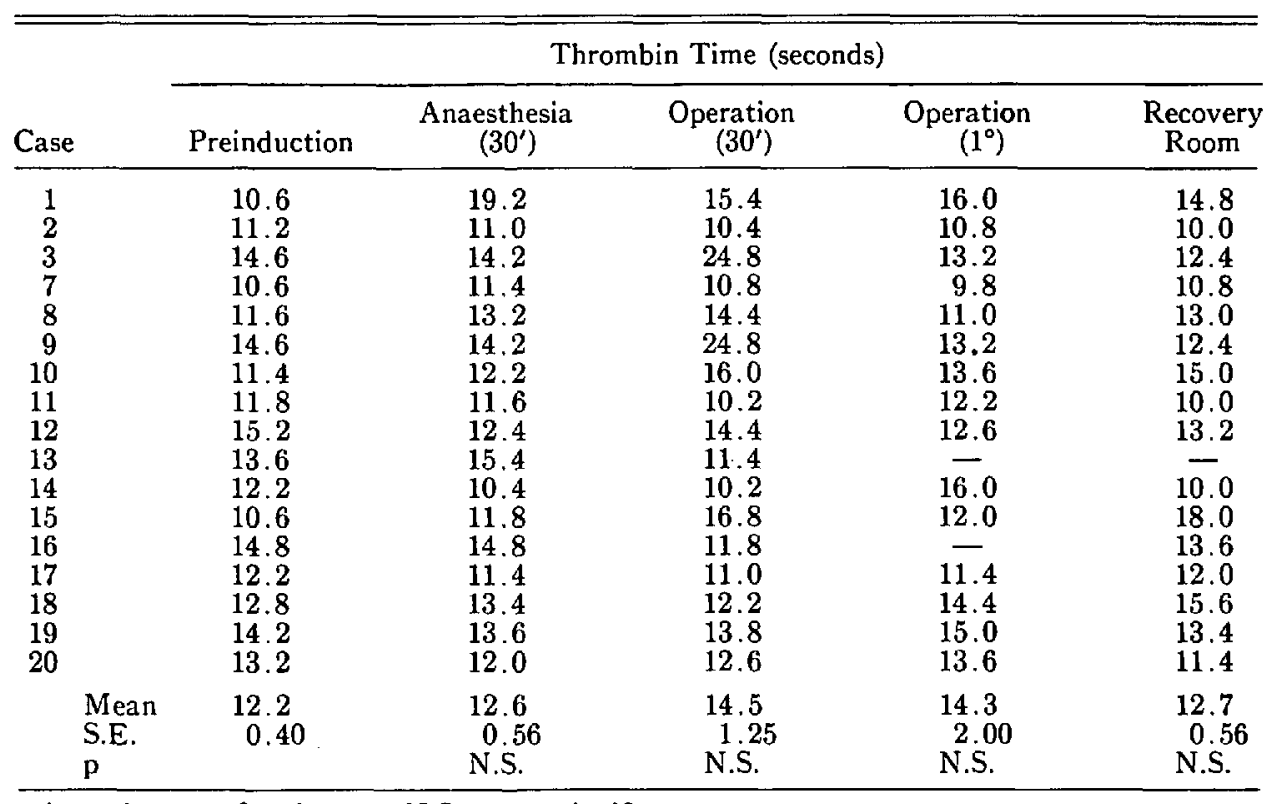

' $=$ minutes. ${ }^{\circ}=$ hours. N.S. $=$ not significant.

TABLE IV

Prothrombin Time During Ëthrane@ Anaesthesia and Surgical Operation

\begin{tabular}{|c|c|c|c|c|c|c|}
\hline \multirow[b]{2}{*}{ Case } & & \multicolumn{5}{|c|}{ Prothrombin Time (seconds) } \\
\hline & & Preinduction & $\begin{array}{c}\text { Anaesthesia } \\
\left(30^{\prime}\right)\end{array}$ & $\begin{array}{l}\text { Operation } \\
\left(30^{\prime}\right)\end{array}$ & $\begin{array}{l}\text { Operation } \\
\left(1^{\circ}\right)\end{array}$ & $\begin{array}{c}\text { Recovery } \\
\text { Room }\end{array}$ \\
\hline $\begin{array}{r}1 \\
2 \\
3 \\
6 \\
7 \\
8 \\
9 \\
10 \\
11 \\
12 \\
13 \\
14 \\
15 \\
16 \\
17 \\
18 \\
19 \\
20\end{array}$ & & $\begin{array}{l}12.2 \\
10.6 \\
14.6 \\
12.8 \\
12.6 \\
17.6 \\
14.6 \\
11.8 \\
14.4 \\
13.2 \\
13.4 \\
15.6 \\
15.0 \\
15.0 \\
12.2 \\
12.8 \\
14.2 \\
13.2\end{array}$ & $\begin{array}{l}11.0 \\
11 . .2 \\
14.4 \\
11.4 \\
12.0 \\
16.8 \\
14.4 \\
11.4 \\
15.0 \\
12.2 \\
14.0 \\
15.0 \\
14.8 \\
15.6 \\
11.4 \\
13.4 \\
13.6 \\
12.0\end{array}$ & $\begin{array}{r}11.8 \\
9.8 \\
15.2 \\
11.8 \\
12.0 \\
15.6 \\
15.2 \\
13.4 \\
13.8 \\
12.8 \\
13.6 \\
14.0 \\
15.0 \\
14.2 \\
11.0 \\
12.2 \\
13.8 \\
12.6\end{array}$ & $\begin{array}{l}10.6 \\
10.8 \\
13.4 \\
11.6 \\
11.6 \\
18.4 \\
13.4 \\
12.8 \\
14.2 \\
12.0 \\
15.4 \\
14.2 \\
17.8 \\
11.4 \\
14.4 \\
15.0 \\
13.6\end{array}$ & $\begin{array}{l}11.2 \\
10.0 \\
14.0 \\
12.0 \\
12.4 \\
17.0 \\
14.0 \\
17.2 \\
12.6 \\
12.6 \\
12.8 \\
14.0 \\
14.2 \\
17.6 \\
12.0 \\
15.6 \\
13.4 \\
11.4\end{array}$ \\
\hline & $\begin{array}{l}\text { Mean } \\
\text { S.E. } \\
\text { p }\end{array}$ & $\begin{array}{c}13.7 \\
0.38\end{array}$ & $\begin{array}{c}13.3 \\
0.41 \\
0.05\end{array}$ & $\begin{array}{c}13.2 \\
0.36 \\
0.05\end{array}$ & $\begin{array}{c}13.6 \\
0.53 \\
\text { N.S. }\end{array}$ & $\begin{array}{c}13.6 \\
0.49 \\
\text { N.S. }\end{array}$ \\
\hline
\end{tabular}

$'=$ minutes. ${ }^{\circ}=$ hours. N.S. $=$ not significant. 
OYAMA, et al.: COAGULATION-FIBRINOLYSIS SYSTEM

TABLE V

Partial Thromboblastin Time During Ethrane ${ }^{\circledR}$ Anaesthesia and Surgical Operation

\begin{tabular}{|c|c|c|c|c|c|c|}
\hline \multirow[b]{2}{*}{ Case } & & \multicolumn{5}{|c|}{ Partial Thromboplastin Time (seconds) } \\
\hline & & Preinduction & $\begin{array}{c}\text { Anaesthesia } \\
\left(30^{\prime}\right)\end{array}$ & $\begin{array}{c}\text { Operation } \\
\qquad\left(30^{\prime}\right)\end{array}$ & $\begin{array}{l}\text { Operation } \\
\left(1^{\circ}\right)\end{array}$ & $\begin{array}{c}\text { Recovery } \\
\text { Room }\end{array}$ \\
\hline $\begin{array}{r}3 \\
6 \\
7 \\
8 \\
9 \\
10 \\
11 \\
12 \\
13 \\
14 \\
15 \\
16 \\
17 \\
18 \\
19 \\
20\end{array}$ & & $\begin{array}{r}70.2 \\
56.0 \\
52.0 \\
100.0 \\
70.2 \\
40.8 \\
69.4 \\
58.0 \\
65.0 \\
47.2 \\
57.0 \\
45.6 \\
62.0 \\
33.0 \\
54.8 \\
78.8\end{array}$ & $\begin{array}{l}64.2 \\
50.0 \\
58.0 \\
84.0 \\
54.2 \\
40.2 \\
84.0 \\
49.0 \\
58.8 \\
54.0 \\
46.0 \\
49.0 \\
50.0 \\
43.0 \\
57.4 \\
55.6\end{array}$ & $\begin{array}{l}58.8 \\
45.0 \\
51.0 \\
63.0 \\
58.8 \\
35.4 \\
48.0 \\
49.0 \\
50.0 \\
40.8 \\
47.0 \\
46.0 \\
52.8 \\
41.8 \\
43.6 \\
63.0\end{array}$ & $\begin{array}{r}54.6 \\
44.0 \\
44.4 \\
67.0 \\
54.6 \\
35.0 \\
43.0 \\
37.6 \\
-\overline{42.0} \\
47.4 \\
108.0 \\
42.6 \\
46.4 \\
57.4 \\
3.0\end{array}$ & $\begin{array}{l}41.4 \\
38.6 \\
47.6 \\
68.0 \\
41.4 \\
47.0 \\
39.0 \\
41.6 \\
63.4 \\
44.0 \\
46.0 \\
45.2 \\
44.4 \\
58.0 \\
42.0 \\
46.2\end{array}$ \\
\hline & $\begin{array}{l}\text { Mean } \\
\text { S.E. } \\
\text { p }\end{array}$ & $\begin{array}{l}60.0 \\
3.89\end{array}$ & $\begin{array}{c}56.7 \\
3.06 \\
\text { N.S. }\end{array}$ & $\begin{array}{l}49.6 \\
1.94 \\
0.001\end{array}$ & $\begin{array}{c}60.3 \\
9.36 \\
\text { N.S. }\end{array}$ & $\begin{array}{c}47.1 \\
2.08 \\
0.01\end{array}$ \\
\hline
\end{tabular}

$'=$ minutes. ${ }^{\circ}=$ hours. N.S. $=$ not significant.

$0.80 \times 10^{-3}$ P.U. ( \pm S.E.). It decreased significantly $(p<0.001) 30$ minutes and one hour after the start of operation. In the recovery room it was still significantly decreased to $13.2 \pm 0.68 \times 10^{-3}$ P.U. $(p<0.001)$ (Table VI).

(b) The fibrinogen level before the induction of anaesthesia was $248.7 \pm 14.56$ $\mathrm{mg} / 100 \mathrm{ml}$ ( \pm S.E.). It decreased to $224.6 \pm 17.43 \mathrm{mg} / 100 \mathrm{ml} 30$ minutes after the induction of anaesthesia, this being within normal range but exhibiting a statistically significant decline $(p<0.05)$. The fibrinogen level decreased gradually and significantly $(p<0.05)$ during operation, being $216.3 \pm 19.35 \mathrm{mg} / 100 \mathrm{ml}$ and $198.1 \pm 19.08 \mathrm{mg} / 100 \mathrm{ml} 30$ minutes and one hour after the start of operation, respectively. It was further reduced to $181.8 \pm 24.96 \mathrm{mg} / 100 \mathrm{ml}$ in the recovery room $(p<0.03)$ (Table VII).

(c) The euglobulin clot lysis time was $226.7 \pm 7.9$ minutes $( \pm$ S.E. $)$ before the induction of anaesthesia. It decreased significantly up to $197.4 \pm 15.84$ minutes 30 minutes after the start of anaesthesia. It decreased significantly $(\mathrm{p}<0.001)$ to $101.1 \pm 18.03$ and $101.0 \pm 17.04$ minutes, respectively, 30 minutes and one hour after the start of operation, but increased to $191.7 \pm 16.86$ minutes in the recovery room, exhibiting the tendency of returning to the control value (Table VIII).

\section{Discussion}

We administered $\overline{\mathrm{E}}$ thrane ${ }^{\circledR}$ anaesthesia for 20 gynaecological operations (mostly panhysterectomy) performed by the same surgeons, and examined the coagulationfibrinolysis system during anaesthesia alone and during operation. The platelets were counted and the coagulation system was evaluated by thrombin time, pro- 
TABLE VI

Plasma Plasminogen levels During Ëthrane® Anaesthesia and Surgical Operation

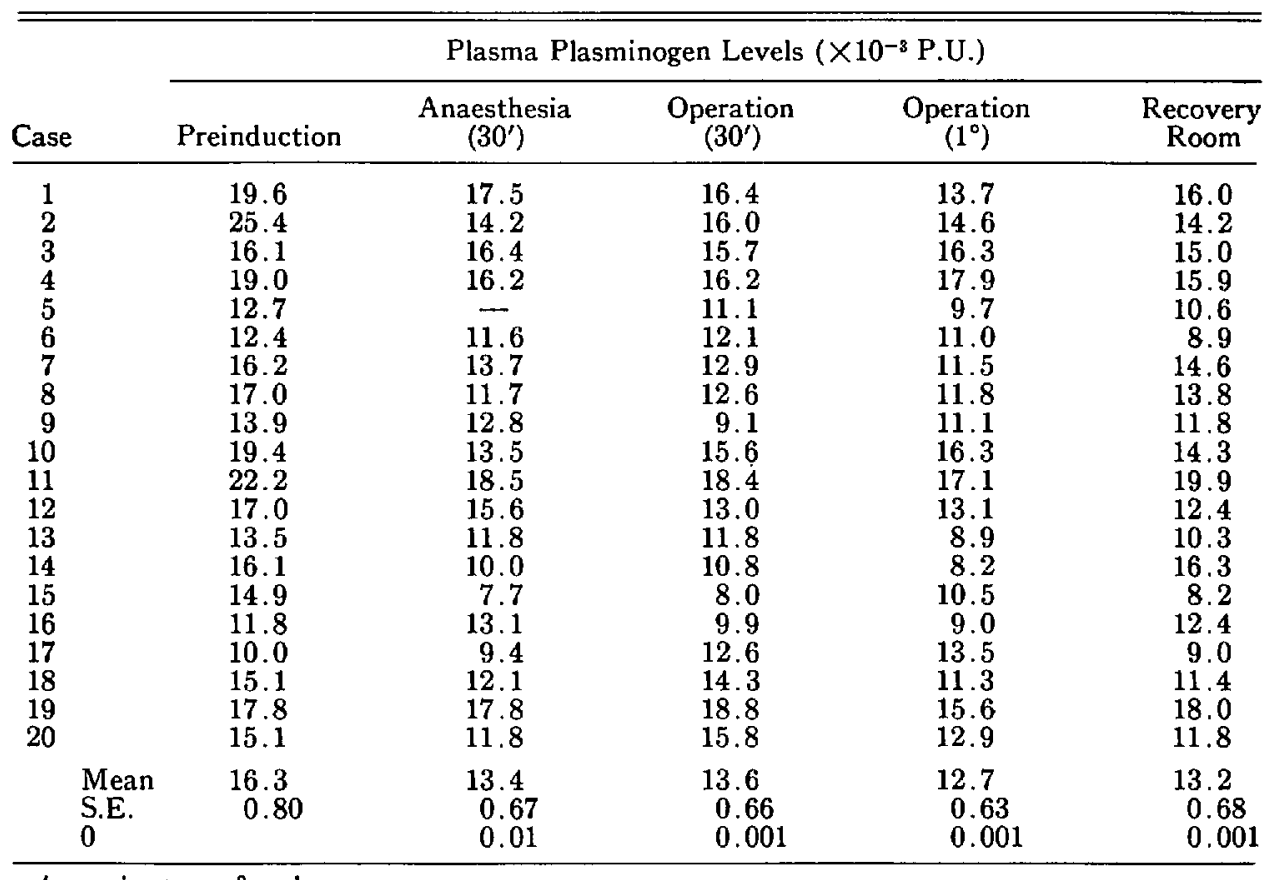

TABLE VII

Plasma Fibrinogen Levels During Ethrane ${ }^{\circledR}$ Anaesthesia and Surgical Operation

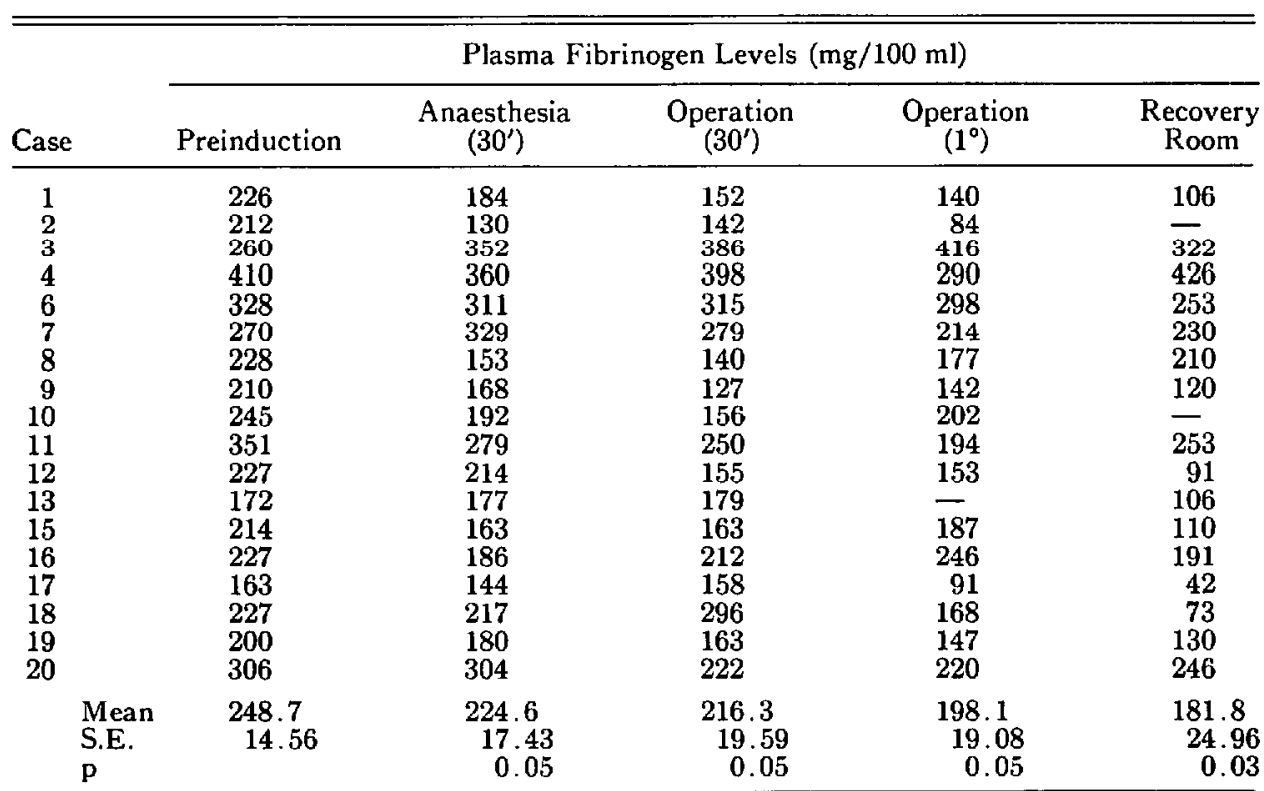

\footnotetext{
$'=$ minutes. ${ }^{\circ}=$ hours.
} 
TABLE VIII

Euglobulin Clot lysis Time During Ethrane@ Anaesthesia and Surgical Operation

\begin{tabular}{|c|c|c|c|c|c|c|}
\hline \multirow[b]{2}{*}{ Case } & & \multicolumn{5}{|c|}{ Euglobulin Clot Lysis Time (minutes) } \\
\hline & & Preinduction & $\begin{array}{c}\text { Anaesthesia } \\
\left(30^{\prime}\right)\end{array}$ & $\begin{array}{l}\text { Operation } \\
\left(30^{\prime}\right)\end{array}$ & $\begin{array}{l}\text { Operation } \\
\left(1^{\circ}\right)\end{array}$ & $\begin{array}{c}\text { Recovery } \\
\text { Room }\end{array}$ \\
\hline 1 & & 240 & 60 & 240 & 60 & 180 \\
\hline 2 & & 240 & 30 & 240 & 120 & 240 \\
\hline 3 & & 240 & 240 & 30 & 90 & 30 \\
\hline 5 & & 240 & 240 & 30 & 120 & 30 \\
\hline 6 & & 240 & 240 & 210 & 240 & 240 \\
\hline 7 & & 240 & 240 & 90 & 60 & 240 \\
\hline 8 & & 240 & 240 & 180 & 210 & 240 \\
\hline 9 & & 240 & 240 & 90 & 120 & 240 \\
\hline 10 & & 240 & 240 & 60 & 90 & 240 \\
\hline 11 & & 240 & 240 & 120 & 240 & 240 \\
\hline 12 & & 240 & 240 & 30 & 30 & 90 \\
\hline 13 & & 150 & 150 & 30 & 30 & 150 \\
\hline 14 & & 240 & 240 & 30 & 30 & 270 \\
\hline 15 & & 120 & 90 & 30 & 30 & 180 \\
\hline 16 & & 210 & 120 & 60 & 60 & 240 \\
\hline 17 & & 240 & 180 & 120 & 60 & 240 \\
\hline 18 & & 240 & 240 & 30 & 30 & - \\
\hline \multirow{5}{*}{$\begin{array}{l}19 \\
20\end{array}$} & & 240 & 240 & 60 & 60 & 150 \\
\hline & & - & 240 & 240 & 240 & 240 \\
\hline & Mean & 226.7 & 197.4 & 101.1 & 101.1 & 191.7 \\
\hline & S.E. & 7.90 & 15.84 & 18.03 & 17.04 & 16.86 \\
\hline & $\mathrm{p}$ & & N.S. & 0.001 & 0.001 & N.S. \\
\hline
\end{tabular}

$'=$ minutes. ${ }^{\circ}=$ hours. N.S. $=$ not significant.

thrombin time and partial thromboplastin time (P.T.T.). They were maintained practically within normal range. Plasminogen and euglobulin clot lysis times decreased significantly during Ethrane ${ }^{\circledR}$ anaesthesia alone for 30 minutes, and a further reduction was noted during the surgical operation. The fibrinogen level also tended to decrease. These findings suggest that $\bar{E}$ thrane anaesthesia and surgical operation accelerated the activity of the fibrinolytic system in man. The elucidation of this accelerated mechanism is beyond the scope of the present study. Administration of low molecular dextran, $1000 \mathrm{ml}$, was not found to cause any significant effect on the coagulation and fibrinolysis system in man. ${ }^{1}$

We have observed acceleration, both in the coagulation and fibrinolysis systems, under halothane anaesthesia, thereby maintaining a balanced haemostatic mechanism." Vanderveen et al. ${ }^{3}$ found mild disturbance in the coagulation system and prolonged bleeding time only during hypothermia. No difference was found in the blood coagulation factors by other methods of anaesthesia or with other anaesthetics. They observed a slight prolongation in the bleeding time and a decline in capillary resistance. Pison et al. ${ }^{4}$ found that the surgical operations increased fibrinolytic activity significantly. Dillon" reported that the volume of bleeding during surgical operations under $\overline{\mathrm{E}}$ thrane ${ }^{\circledR}$ anaesthesia, was as normal as in other ordinary surgical operations.

The haemorrhagic diathesis is considered to be induced by abnormalities, platelets, blood vessels, coagulation, and fibrinolysis. The coagulation and fibrinolysis systems are collectively designated as the coagulation-fibrinolysis system. Under normal conditions there is constantly a dynamic equilibrium between the coagu- 
lation and the fibrinolysis systems. When the equilibrium is upset by various stresses including surgery, anaesthesia, shock, anoxia, a variety of disturbances are produced. When the coagulation system is predominant, thrombus may be formed. Conversely, if the fibrinolytic system is predominant oozing may result in severe haemorrhage. ${ }^{8}$

$\bar{E}$ thrane ${ }^{\circledR}$ anaesthesia showed a tendency to accelerated plasmin activity and decreased fibrinogen level. This might be interpreted as setting the stage for the development of a haemorrhagic tendency but in fact the changes are not so extensive as to warrant such an interpretation. It may be suggested that both anaesthesia and surgical operation are conducive to acceleration of coagulation and fibrinolysis, but, the haemostatic mechanism tends to keep a balance between coagulation and fibrinolysis and to be in equilibrium.

It is common knowledge that a haemorrhagic tendency becomes overt when the factors participating in the haemostatic mechanism are reduced to less than 20 per cent of normal. Therefore, although $\bar{E}$ thrane ${ }^{\circledR}$ anaesthesia causes increased fibrinolysis and decreases fibrinogen level, unless the haemostatic mechanisms have been abnormal before operation no decline below the borderline levels can be observed. However, it should be kept in mind that Ethrane seems to cause more fibrinolysis and a lower level of fibrinogen than is the case with other anaesthetics. ${ }^{2}$ The possible need for an antiplasmin agent during operation should also be considered.

\section{SUMMARY}

The coagulation-fibrinolysis system was studied during Ėthrane ${ }^{\circledR}$ anaesthesia and gynaecological operations in 20 patients.

No particular change was noted in the platelet counts, which remained within the normal range. In the coagulation system, no appreciable change was observed except for the partial thromboplastin time( P.T.T.) which was significantly shortended, both 30 minutes after the start of operation and in the recovery room when the patient had completely awakened from the anaesthesia.

In the fibrinolytic system, the plasminogen level and the fibrinogen level declined significantly.

It is considered that the fibrinolytic system is prominently accelerated under Ethrane ${ }^{\circledR}$ anaesthesia, but the haemostatic mechanism works in such a manner that bleeding is controlled. However, Ethrane ${ }^{\circledR}$ anaesthesia should be avoided or pre-operative administration of an antiplasmic agent recommended for patients with an abnormal haemostatic mechanism.

\section{RÉSUMÉ}

1. Le système coagulation-fibrinolyse a été étudié chez 20 patientes au cours d'interventions gynécologiques, sous anesthésie à l'Ethrane.

2. Aucune modification particulière ne fut trouvée dans la numération plaquettaire qui est demeurée dans les limites normales. Le coagulogramme n'a pas été modifié de façon appréciable sauf le temps de thromboplastine partiel (P.T.T.) qui 
était diminué de façon significative, ceci après 30 minutes de chirurgie et après l'éveil complet.

3. Pour ce qui est du système fibrinolytique, les taux de plasminogène et de fibrinogène étaient diminués de façon significative; le fibrinogène en particulier était abaissé de façon marquée.

4. Nous considérons que sous anesthésie à l'Ethrane, le système fibrinolytique est accéléré, mais que les mécanismes hémostatiques agissent de telle façon que l'hémorragie est contrôlée.

Cependant, chez les patients présentant des troubles de l'hémostase, on devrait éviter l'anesthésie à l'Ethrane à moins de leur administrer un agent antifibrinoly. tique avant l'intervention.

\section{REFERENCES}

1. Oyama, T. Effect of low molecular weight dextran on coagulative-fibrinolytic system in man (to be published).

2. Oyama, T, TAkicuchi, M., Kimura, K., \& Maki, M. Effect of fluothane anesthesia on coagulative-fibrinolytic system. Jap. J. Anesthesiol. 16: 686-692 (1967).

3. Venderveen, J. L., MCGovern, J.J., Bunker, J.P., \& Goldstein, R. Effect of anesthesia on hemostatic mechanism in man. Anesthesiology 23: 92-100 (1962).

4. Pison, J., Boyan, C.P., \& Cliffton, E.E. Fibrinolytic activity in patients during operation. J.A.M.A. 191: 1026-1027 (1965).

5. Dillon, J.B., Lebowitz, M.H., \& Blitt, C.D. Clinical investigation of compound 347 (Ethrane(1) ). Anesth. Analg. 49: 1-10 (1970).

6. Roderique, E.M. \& Wynands, J.E. Blood coagulation and hemostasis. A review. Canad. Anaesth. Soc. J. 14: 129-151 (1967). 